\title{
Adult Plant Resistance of Selected Kenyan Wheat Cultivars to Leaf Rust and Stem Rust Diseases
}

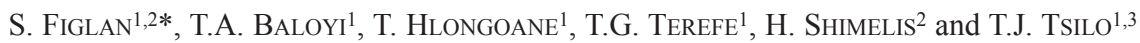 \\ ${ }^{1}$ Agricultural Research Council-Small Grain Institute (ARC-SGI), Bethlehem, South Africa \\ ${ }^{2}$ School of Agricultural, Earth and Environmental Sciences, University of KwaZulu-Natal, \\ Pietermaritzburg, South Africa \\ ${ }^{3}$ Department of Life and Consumer Sciences, University of South Africa, Pretoria, South Africa
}

(Received 2 August 2016; Accepted 16 September 2016;

Communicated by J. Kolmer)

\begin{abstract}
Phenotypic and genotypic evaluation of wheat genetic resources and development of segregating populations are pre-requisites for identifying rust resistance genes. The objectives of this study were to assess adult plant resistance (APR) of selected wheat genotypes to leaf rust and stem rust and to develop segregating populations for resistance breeding. Eight selected Kenyan cultivars with known resistance to stem rust, together with local checks were evaluated for leaf rust and stem rust resistance at seedling stage and also across several environments. Selected diagnostic markers were used to determine the presence of known genes. All eight cultivars were crossed with local checks using a bi-parental mating design. Seedling tests revealed that parents exhibited differential infection types against wheat rust races. Cultivars Paka and Popo consistently showed resistant infection types at seedling stage, while Gem, Romany, Pasa, Fahari, Kudu, Ngiri and Kariega varied for resistant and susceptible infection types depending on the pathogen race used. The control cultivars Morocco and McNair consistently showed susceptible infection types as expected. In the field, all cultivars except for Morocco showed moderate to high levels of resistance, indicating the presence of effective resistance genes. Using diagnostic markers, presence of Lr34 was confirmed in Gem, Fahari, Kudu, Ngiri and Kariega, while Sr2 was present in Gem, Romany, Paka and Kudu. Seedling resistance gene, Sr35, was only detected in cultivar Popo. Overall, the study developed $909 \mathrm{~F}_{6: 8}$ recombinant inbred lines (RILs) as part of the nested mating design and are useful genetic resources for further studies and for mapping wheat rust resistance genes.
\end{abstract}

Keywords: adult plant resistance, leaf rust, population development, stem rust, wheat

\section{Introduction}

A number of wheat diseases cause significant yield loss and increased cost of production. Stem rust, caused by the fungus Puccinia graminis f. sp. tritici (Pgt) and leaf rust by P. triticina Eriks. (Pt) are the most widely distributed and yield limiting diseases in South Africa (Pretorius et al. 2007). The recent detection of new virulent leaf rust races such as

\footnotetext{
*Corresponding author; E-mail: figlans@arc.agric.za
}

This is an open-access article distributed under the terms of the Creative Commons Attribution License, which permits unrestricted use, distribution, and reproduction in any medium for non-commercial purposes, provided the original author and source are credited. 
CCPS, MCDS and FBPT (Pretorius et al. 2015) and four highly virulent Ug99 variants including TTKSF, TTKSP, PTKST and TTKSF+ (http://rusttracker.cimmyt.org/?page $\mathrm{id}=22$ ) present a significant threat to wheat production in South Africa, necessitating integrated and collaborative management strategies of the diseases.

Host-plant resistance to wheat diseases is the most effective, environmentally and economically sustainable approach to reduce yield losses compared to the use of crop protection chemicals (Pretorius et al. 2007; McCallum et al. 2016). Breeding of wheat cultivars with durable resistance to rust diseases is the best control strategy (Kolmer 1996; Singh et al. 2005). Therefore, identification of sources of resistance and candidate genes remain important for breeding purposes.

Disease resistance can be broadly categorised as race-specific or race non-specific. Race-specific (vertical resistance) is conditioned by major genes and can be detected at a seedling or adult plant stage. Race non-specific resistance (horizontal resistance) is controlled by minor genes and remains effective against all races of the pathogen and is expressed at an adult plant stage, as partial and slow rusting resistance (Parlevliet and van Ommeren 1975; Johnson 1984; Singh 1992; Kolmer 1996). Race-specific resistance has been widely employed by various wheat improvement programmes. However, this form of resistance is frequently defeated by the appearance of new and virulent races of the pathogen population through a single-step mutation and/or sexual recombination events (Kolmer 2005; Terefe et al. 2014; Kolmer and Acevedo 2016). Race non-specific resistance confers long-term and durable resistance (Singh et al. 2000, 2005). However, progress on breeding for durable resistance is slow, requiring identification and pyramiding of novel, adult plant resistance (APR) genes into a desirable genotype. So far, few APR genes have been characterized and catalogued in wheat (Krattinger et al. 2009; HerreraFoessel et al. 2011, 2012; Bansal et al. 2014). Screening for APR genes requires proper phenotyping to correctly detect their expression in the field. Often genotypes with APR may show susceptibility at the seedling stage, but adult plants show low disease severity. Efficient characterisation of APR genes requires development of segregating populations that can be used to dissect and identify genomic regions controlling such resistance. There is evidence that most APR genes are effective across a number of pathogens, e.g. Sr2/ Yr30/Lr27/Pbc1, Sr55/Lr67/Yr46/Pm46/Ltn3, Sr57/Lr34/Yr18/Pm38/Ltn1 and Sr58/ Lr46/Yr29/Pm39/Ltn2 (William et al. 2006; Lillemo et al. 2008; Krattinger et al. 2009; Mago et al. 2011a; Herrera-Foessel et al. 2014; Kolmer et al. 2015). Several Kenyan cultivars have been shown to be good sources of APR genes controlling stem rust (Knott 1968; Njau et al. 2009, 2010; Onguso and Njau 2015; Bajgain et al. 2016).

The objectives of this study were to assess leaf rust and stem rust resistance of selected Kenyan cultivars, determine the presence of APR genes, and to develop a nested bi-parental mapping population that could be used for genetic studies and for validation of APR genes. 


\section{Material and Methods}

\section{Plant material and seedling screening}

Eight Kenyan bread wheat cultivars (Gem, Romany, Paka, Fahari, Kudu, Pasa, Ngiri and Popo) with known stem rust resistance (Njau et al. 2009; Bajgain et al. 2016), together with four local checks (Kariega, Morocco, McNair and SST88) were used for the study. Seeds of the cultivars were obtained from the National Small Grain Germplasm Collection of the Agricultural Research Council-Small Grain Institute (ARC-SGI) in Bethlehem. The genotypes were screened in a glasshouse for seedling resistance to leaf rust and stem rust at ARC-SGI. Cultivars together with rust susceptible checks SST88 and McNair were sown in sterilised soil in $10 \mathrm{~cm}$ diameter plastic pots under a temperature-controlled seedling room at 20 to $25^{\circ} \mathrm{C}$. Five seeds from each of the cultivars were sown, with three replicates per genotype. After emergence, plants were fertilised twice with $10 \mathrm{~g} \mathrm{l}^{-1} \mathrm{Multi}-$ feed water soluble fertiliser (19:8:16 NPK plus micronutrients).

The genotypes were tested using six South African stem rust races (TTKSF+: 2SA88+, TTKSF: 2SA88, BPGSC+Sr27: 2SA102, BPGSC+Sr27+Kiwiet+Satu: 2SA105, TTKSP: 2SA106 and PTKST: 2SA107) and four leaf rust races (PDRS: 3SA133, SDDN: 3SA144, CCPS: 3SA145 and MCDS: 3SA146). Some of the races used in the study are most prevalent in the South African Development Community (SADC) region. The urediniospores of the leaf rust and stem rust races were obtained from regularly maintained stocks stored in a $-80{ }^{\circ} \mathrm{C}$ freezer at ARC-SGI. Plants were infected using the established inoculation protocol (Pretorius et al. 2000). Infection types were scored 14 days post inoculation using a scale of 0-4 according to Stakman et al. (1962) for stem rust and Long and Kolmer (1989); Pretorius et al. (2000) for leaf rust; where a score of 0 represents immune with no sign of infection, 0 ; nearly immune with a few faint flecks, ; very resistant with no uredinia but hypersensitive necrotic or chlorotic flecks are present, 1; resistant with small uredinia often surrounded by necrosis, 2 ; moderately resistant with small to medium uredinia often surrounded by necrosis, 3 ; moderately susceptible with medium sized uredinia without chlorosis or necrosis and 4 represents very susceptible with large uredinia without chlorosis or necrosis.

\section{Field screening for adult plant resistance}

The genotypes were evaluated under field conditions for resistance to leaf rust and stem rust. Evaluations were conducted across two wheat-growing locations in South Africa, (Cedara situated in KwaZulu-Natal Province in 2014 and 2015) and (Tygerhoek, in Western Cape Province in 2015). The locations differed in soil conditions, temperature and moisture and are hot spot areas for wheat rust pathogens and are annually surveyed for rust races. Hence, the locations were selected based on the known prevalence of the two diseases in the past. The cultivars were replicated five times in each environment. Approximately 20 seeds from each cultivar were sown in hill plots. Rust susceptible cultivars Morocco, SST88 and McNair were planted as spreader rows around the experimental area to ensure disease initiation and spread. All cultural practices such as fertilisation, 
irrigation and other management practices were followed according to the recommendation of the specific areas.

Field infection response of the cultivars were visually assessed. Disease severity was recorded using a modified Cobb scale of 0 to 10 (Peterson et al. 1948; Tsilo et al. 2014); where scores of 0 to 2 represent highly resistant, 3 resistant, 4 to 5 moderately resistant, 6 to 7 moderately susceptible, 8 susceptible and 9 to 10 highly susceptible. The disease severity of leaf rust and stem rust was recorded only once in each season on adult plants when the disease symptoms were fully developed on the susceptible checks Morocco, SST 88 and McNair displaying $80 \%$ or higher disease severity. The cultivars were screened in the field mainly to identify cultivars with adult plant resistance (APR).

\section{Data analysis}

Disease severity score for each cultivar from all the environments were collected to determine the overall response to leaf rust and stem rust. Analysis of variance using the severity scores of test genotypes was performed using the general linear model procedure (PROC GLM) in SAS software (version 9.3, SAS Institute Inc, Cary NC, USA).

\section{Homogenisation of leaf samples and DNA extraction}

Three to four leaves from each of the test cultivars were harvested from ten-day-old seedling plants for DNA sampling. Leaves were placed in $2 \mathrm{ml}$ Eppendorf tubes and stored in $\mathrm{a}-80{ }^{\circ} \mathrm{C}$ freezer prior to DNA extraction. To homogenise the samples during DNA extraction, two round stainless-steel ball bearings ( $5 \mathrm{~mm}$ in diameter) were added to the frozen leaf material in $2 \mathrm{ml}$ Eppendorf tubes. The frozen leaf material was homogenised using Qiagen's Tissue Lyser for $1 \mathrm{~min}$ at $30 \mathrm{r} / \mathrm{s}$. Genomic DNA was isolated using the modified CTAB method (Porebski et al. 1997). The quality, purity and quantity of the extracted DNA was tested using the Nano-Drop 1000 Spectrophotometer (Nano-Drop Technologies, Wilmington, DE, USA).

\section{Genotyping}

DNA samples from all cultivars were screened using diagnostic markers based on protocols for marker-assisted selection (http://maswheat.ucdavis.edu/). Table 1 shows information on the markers used in this study and related references. The Sr31 marker was included in the screening, though no longer effective, mainly to test if the cultivars carried the gene. PCR products were resolved on $1 \%(\mathrm{w} / \mathrm{v})$ agarose - tris-borate - ethylenediaminetetraacetic acid (TBE) gel stained with a highly sensitive stain for DNA visualization SYBR ${ }^{\circledR}$ Safe. 


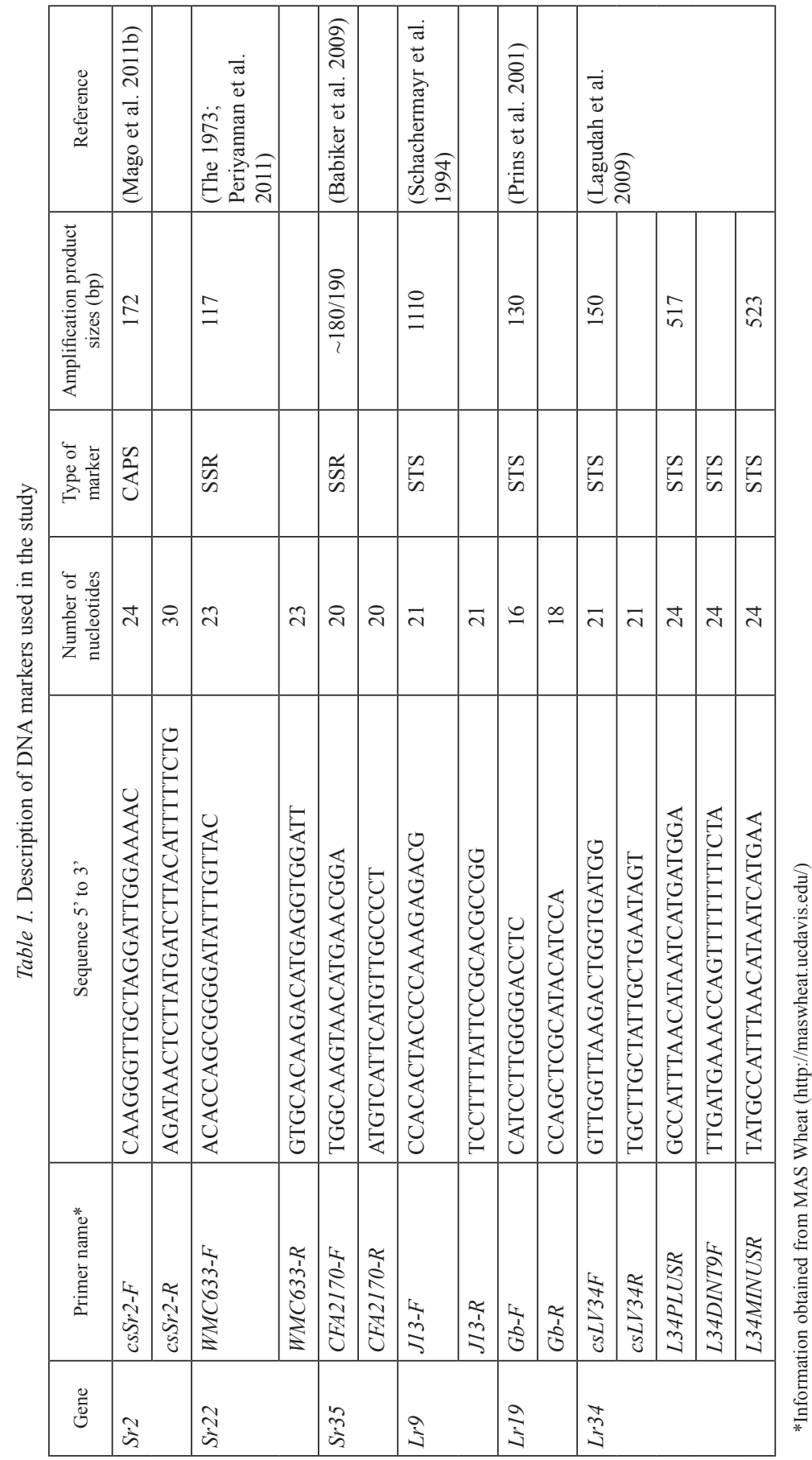




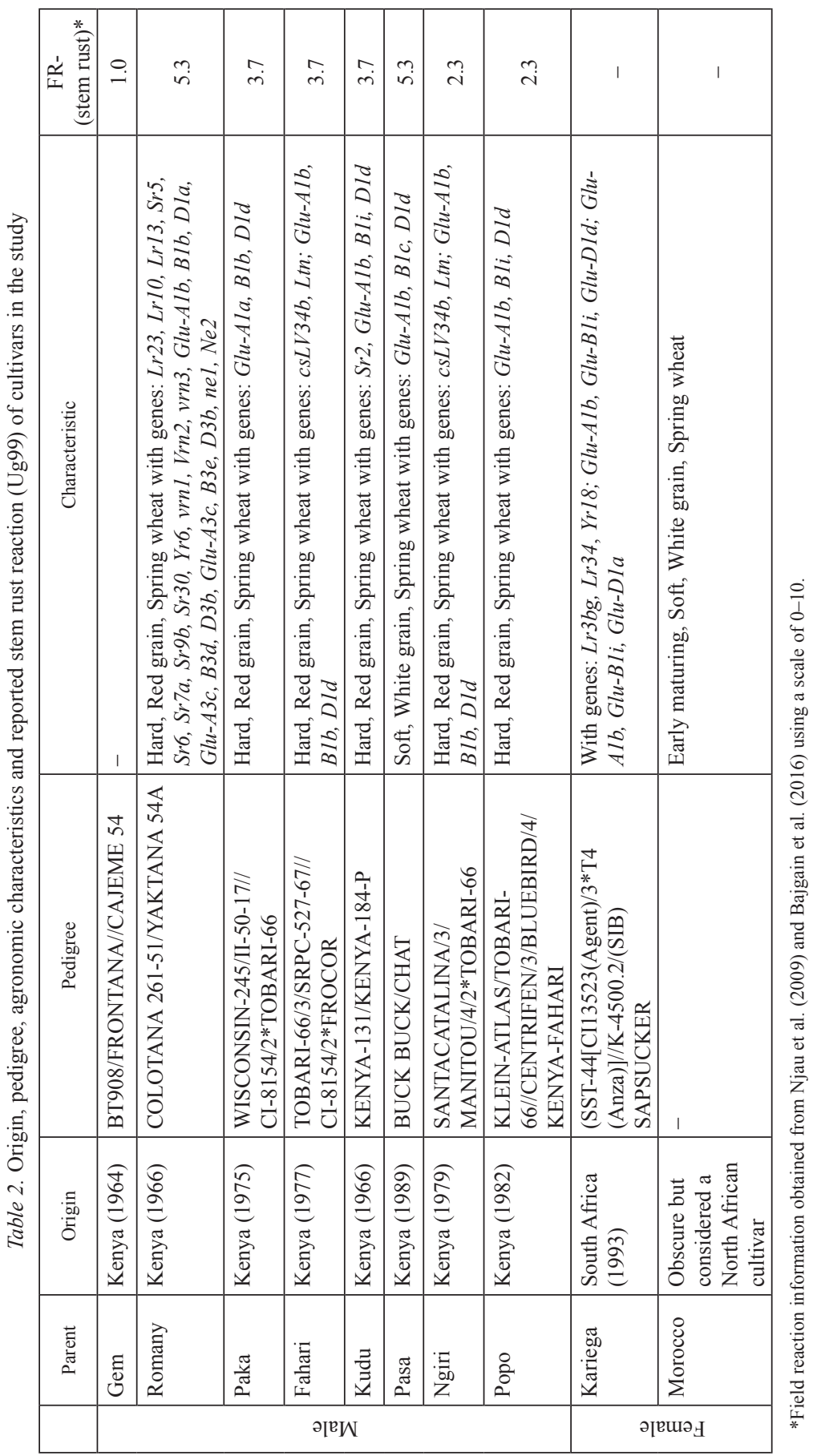

Cereal Research Communications 45, 2017 


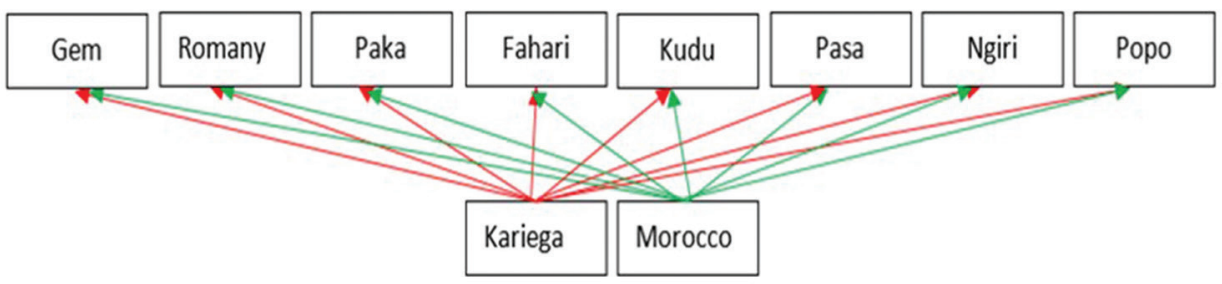

Figure 1. Scheme showing crosses of 10 wheat cultivars to develop bi-parental populations

\section{Development of a nested bi-parental population}

A nested bi-parental population was developed involving crosses of eight Kenyan cultivars (Gem, Romany, Paka, Fahari, Kudu, Pasa, Ngiri and Popo) with two of the four local checks (Kariega and Morocco) (Fig. 1). The cultivars used for the crosses were chosen because of their known resistance to wheat diseases, acceptable end-use quality and yield. Kenyan cultivars also carry many $\mathrm{Sr}$ genes (McIntosh et al. 1995; Njau et al. 2009, 2010; Bajgain et al. 2016), hence the strategic inclusion of these cultivars in the study. Table 2 shows the characteristics of each cultivar used to develop the nested bi-parental population.

Seeds were planted in sterilised soil in $40 \mathrm{~cm}$ diameter plastic pots placed in a temperature-controlled greenhouse at $18-25^{\circ} \mathrm{C}$ and natural photoperiods (14-16 h). Pollen from each of the eight Kenyan cultivars was used to pollinate the emasculated Kariega and Morocco heads (the eight Kenyan cultivars were used as males, and the two checks as females). All $F_{1}$ seed from each successful combination/population were planted in pots in the glasshouse, producing the $\mathrm{F}_{2}$ seed. Approximately 300-400 $\mathrm{F}_{2}$ seeds from each population were planted in trays in the greenhouse and upon harvest, a single seed was randomly selected from each $\mathrm{F}_{2}$ plant and used to produce $\mathrm{F}_{3}$ generation. A single seed descent selection protocol was followed for three additional generations, producing $\mathrm{F}_{6}$ seeds. After the last self-pollination cycle, every line was bulk harvested twice in the field (Bethlehem and Cedara) for multiplication purposes to produce $\mathrm{F}_{6: 8}$ seeds.

\section{Results}

\section{Stem rust reaction of wheat cultivars at seedling stage}

All wheat cultivars displayed differential infection types to the stem rust races used. Overall, cultivars displayed susceptible infection types at seedling stage to the two diseases with the exception of Paka and Popo which consistently showed resistant infection types (IT of ; to 2). All other cultivars (Gem, Romany, Pasa, Fahari, Kudu, Ngiri and Kariega) displayed ITs of 3 to 4 depending on the race used, whilst Morocco and susceptible check McNair consistently showed highly susceptible infection type (IT of 4) (Table 3). 
Table 3. Seedling infection types (IT) of wheat cultivars to various stem rust races prevalent in South Africa

\begin{tabular}{|c|c|c|c|c|c|c|c|}
\hline & \multirow{2}{*}{ Cultivar } & \multicolumn{6}{|c|}{ Stem rust races\# } \\
\hline & & TTKSF+ & TTKSF & $\mathrm{BPGSC}+\operatorname{Sr} 27$ & $\begin{array}{c}\text { BPGSC }+ \text { Sr27+ } \\
\text { Kiwiet }+ \text { Satu }\end{array}$ & TTKSP & PTKST \\
\hline \multirow{11}{*}{ 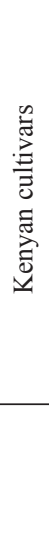 } & Gem & 3 & $3+$ & 3 & 3 & 3 & 3 \\
\hline & Romany & 3 & $3+$ & 3 & 3 & 4 & 4 \\
\hline & Pasa & 3 & 3 & 3 & 3 & 3 & 3 \\
\hline & Fahari & 4 & $3+$ & 4 & 3 & 3 & 3 \\
\hline & Kudu & 3 & 3 & 3 & 3 & 3 & $3+$ \\
\hline & Paka & 1 & 1 & $; 1$ & 1 & $; 1$ & 1 \\
\hline & Ngiri & 3 & $3+$ & 3 & 3 & 3 & 3 \\
\hline & Popo & 2 & 2 & $1+$ & 2 & $1+$ & $1+$ \\
\hline & Kariega* & 3 & 3 & 3 & 3 & 3 & 3 \\
\hline & Morocco* & 4 & 4 & 4 & 4 & 4 & 4 \\
\hline & McNair* & 4 & 4 & 4 & 4 & 4 & 4 \\
\hline
\end{tabular}

*Checks, \#A scale of 0-4 was used according to Stakman et al. (1962).

Table 4. Stem rust disease severity of wheat cultivars across environments

\begin{tabular}{|c|c|c|c|c|c|c|}
\hline & \multirow{2}{*}{ Cultivar } & \multicolumn{5}{|c|}{ Stem rust field screening\# } \\
\hline & & Tygerhoek 2015 & Cedara 2014 & Cedara 2015 & Mean & Std Dev \\
\hline \multirow{11}{*}{ 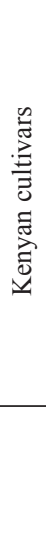 } & Gem & 3 & 3 & 3 & 3 & 0 \\
\hline & Romany & 1 & 5 & 3 & 3 & 1.79 \\
\hline & Pasa & 5 & 6 & 6 & 5.67 & 0.52 \\
\hline & Fahari & 3 & 4 & 4 & 3.67 & 0.52 \\
\hline & Kudu & 2 & 3 & 3 & 2.67 & 0.52 \\
\hline & Paka & 4 & 5 & 4 & 4.33 & 0.52 \\
\hline & Ngiri & 3 & 3 & 2 & 2.67 & 0.52 \\
\hline & Popo & 2 & 2 & 3 & 2.33 & 0.52 \\
\hline & Kariega* & 4 & 5 & 5 & 4.67 & 0.52 \\
\hline & Morocco* & 9 & 10 & 9 & 9.33 & 0.52 \\
\hline & McNair* & 9 & 10 & 10 & 9.67 & 0.52 \\
\hline
\end{tabular}

*Checks, \#A scale of 0-10 was used according to modified Cobb scale Peterson et al. (1948) and Tsilo et al. (2014) 
Stem rust reaction of wheat cultivars at adult plant stage

The selected cultivars except for Morocco also displayed moderately resistant to resistant reactions to stem rust at adult plant stage (Table 4). Cultivars Morocco and McNair consistently showed highly susceptible reactions across testing environments. Analysis of variance indicated highly significant differences between the genotypes, environment and genotype-by-environment interaction $(P=0.0001)$.

\section{Leaf rust reaction of wheat cultivars at seedling stage}

Similarly, all wheat cultivars displayed differential infection types to the leaf rust races used. Cultivars displayed resistant to susceptible infection types at seedling stage. Gem, Paka, and Popo are the only genotypes that consistently showed resistant infection types (IT of 2 or lower), with Pasa showing resistant to moderately resistant infection types (IT 2 to 2+). Other cultivars (Romany, Fahari, Kudu, Ngiri and Kariega) showed both resistant or susceptible infection types (IT of 2 to 4 ) depending on the test race used, whilst Morocco and McNair consistently showed highly susceptible infection types (IT of 4) (Table 5).

Table 5. Seedling infection types (IT) of wheat cultivars to various leaf rust races prevalent in South Africa

\begin{tabular}{|c|c|c|c|c|c|}
\hline & \multirow{2}{*}{ Cultivar } & \multicolumn{4}{|c|}{ Leaf rust races\# } \\
\hline & & PDRS & SDDN & CCPS & MCDS \\
\hline \multirow{11}{*}{ 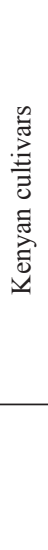 } & Gem & 2 & 2 & 2 & 2 \\
\hline & Romany & 3 & 3 & 3 & 3 \\
\hline & Pasa & 2 & 2 & 2 & $2+$ \\
\hline & Fahari & 3 & $3+$ & 4 & 3 \\
\hline & Kudu & 3 & 3 & $3+$ & 2 \\
\hline & Paka & 1 & 1 & ;1 & 1 \\
\hline & Ngiri & 3 & $3+$ & 3 & 2 \\
\hline & Popo & ;1 & 2 & 1 & 2 \\
\hline & Kariega* & 3 & 3 & 2 & 3 \\
\hline & Morocco* & 4 & 4 & 4 & 4 \\
\hline & McNair* & 4 & 4 & 4 & 4 \\
\hline
\end{tabular}

*Checks, \#A scale of 0-4 was used according to Stakman et al. (1962). 
Table 6. Leaf rust disease severity of wheat parental cultivars across environments

\begin{tabular}{|c|c|c|c|c|c|c|}
\hline & \multirow[b]{2}{*}{ Cultivar } & \multicolumn{5}{|c|}{ Leaf rust field screening\# } \\
\hline & & $\begin{array}{c}\text { Tygerhoek } \\
2015\end{array}$ & Cedara 2014 & Cedara 2015 & Mean & Std Dev \\
\hline \multirow{11}{*}{ 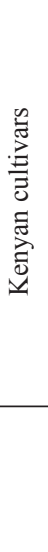 } & Gem & 2 & 2 & 3 & 2.33 & 0.52 \\
\hline & Romany & 1 & 3 & 2 & 2.00 & 0.89 \\
\hline & Pasa & 4 & 6 & 4 & 4.67 & 1.03 \\
\hline & Fahari & 3 & 2 & 5 & 3.33 & 1.37 \\
\hline & Kudu & 2 & 2 & 2 & 2.00 & 0.00 \\
\hline & Paka & 4 & 5 & 5 & 4.67 & 0.52 \\
\hline & Ngiri & 3 & 5 & 4 & 4.00 & 0.89 \\
\hline & Popo & 2 & 3 & 3 & 2.67 & 0.52 \\
\hline & Kariega* & 5 & 5 & 5 & 5.00 & 0.00 \\
\hline & Morocco* & 9 & 10 & 9 & 9.33 & 0.52 \\
\hline & SST88* & 9 & 10 & 10 & 9.67 & 0.52 \\
\hline
\end{tabular}

*Checks, \#A scale of 0-10 was used according to modified Cobb scale Peterson et al. (1948) and Tsilo et al. (2014).

Table 7. Presence of leaf and stem rust resistance genes in selected wheat cultivars

\begin{tabular}{|c|c|c|c|c|c|c|c|c|}
\hline & \multirow{2}{*}{ Cultivar } & \multicolumn{7}{|c|}{ Marker screening } \\
\hline & & $S r 2 / L r 27$ & $\operatorname{Sr} 22$ & Sr 31 & Sr35 & $\operatorname{Lr} 9$ & $\operatorname{Lr} 19$ & $\operatorname{Lr} 34 / S r 57$ \\
\hline \multirow{11}{*}{ 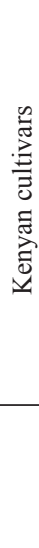 } & Gem & + & - & - & - & - & - & + \\
\hline & Romany & + & - & - & - & - & - & - \\
\hline & Pasa & - & - & - & - & - & - & - \\
\hline & Fahari & - & - & - & - & - & - & + \\
\hline & Kudu & + & - & - & - & - & - & + \\
\hline & Paka & + & - & - & - & - & - & - \\
\hline & Ngiri & - & - & - & - & - & - & + \\
\hline & Popo & - & - & - & + & - & - & - \\
\hline & Kariega* & - & - & - & - & - & - & + \\
\hline & Morocco* & - & - & - & - & - & - & - \\
\hline & Control $(+v e)$ & + & + & + & + & + & + & + \\
\hline
\end{tabular}

*Cultivars used as local checks, + denotes present, - denotes absent. 


\section{Leaf rust reaction of wheat cultivars at adult plant stage}

All test genotypes except Morocco and SST88, displayed moderately resistant to resistant reactions at adult plant stage (Table 6). Morocco and SST88 consistently showed highly susceptible reactions in all field environments. Analysis of variance indicated highly significant differences between the genotypes, environment and genotype-by-environment interaction $(P=0.0001)$.

\section{Identification of leaf rust and stem rust resistance genes using molecular markers}

Genotyping with marker J13 and marker Gb linked to leaf rust seedling resistance genes Lr9 and $\operatorname{Lr} 19$, respectively, did not yield any positive PCR product in all cultivars. For stem rust, as expected the results indicated that none of the parental cultivars contain the gene $S r 22$ when screened with marker WMC633. Cultivar Popo was screened positive for $\mathrm{Sr} 35$. The markers linked to pleiotropic and adult plant resistant genes $\mathrm{Lr} 34 / \mathrm{Sr} 57$ and $\mathrm{Sr}$ / Lr27 were also tested. Of the selected cultivars, five (Gem, Fahari, Kudu, Ngiri and Kariega) tested positive for $\mathrm{Lr} 34 / \mathrm{Sr} 57$, four (Gem, Romany, Kudu and Paka) tested positive for $S r 2 / L r 27$ while two (Gem and Kudu) carried both APR genes (Table 7).

\section{Development of a nested bi-parental population}

Several lines were lost over the cycles of single seed descent selection and populations with less than 100 lines were not included in the panel, resulting to the final number of 7 bi-parental populations with a total of $909 \mathrm{~F}_{6: 8}$ recombinant inbred lines (RILs) (Table 8).

Table 8. Nested bi-parental population developed and advanced to $\mathrm{F}_{6: 8}$ generation

\begin{tabular}{|l|c|c|}
\hline \multicolumn{1}{|c|}{ Cross } & Designated name & No. of RILs \\
\hline Popo/Kariega & TF4 & 179 \\
\hline Popo/Morocco & TF5 & 121 \\
\hline Romany/Kariega & TF6 & 109 \\
\hline Paka/Kariega & TF7 & 124 \\
\hline Gem/Kariega & TF11 & 128 \\
\hline Fahari/Morocco & TF13 & 132 \\
\hline Fahari/Kariega & TF14 & 116 \\
\hline Total & & 909 \\
\hline
\end{tabular}




\section{Discussion}

Previous studies have shown that Kenyan cultivars are good sources of stem rust resistance (Njau et al. 2009; Knott 1968), specifically the resistance expressed at an adult plant stage. This has been attributed mainly to the presence of $\mathrm{Sr} 2$ gene complex, either as the sole source of resistance or in combination with other minor and major genes. In the current study, the results of seedling tests against 6 stem rust races predominant in South Africa showed that most Kenyan cultivars displayed highly susceptible infection types at a seedling stage, with the exception of Paka and Popo. The same susceptibility was reported against Ug99 races (TTKS and TTKSK) at seedling stage (Njau et al. 2009; Bajgain et al. 2016). However, all these Kenyan cultivars showed good level of resistance at seedling stage to all predominant races of stem rust in the U.S.A (Njau et al. 2009; Bajgain et al. 2016) but not against African races (results of all studies including the current), implying that these cultivars, with the exception of Paka and Popo, did not express effective race-specific genes to South African races including the Ug99 race group.

Nevertheless, all eight of these Kenyan cultivars displayed high levels of resistance to stem rust in three environments in South Africa. Similar trends were previously observed, with Kenyan cultivars (including all those used in the current study) showing susceptible infection types at the seedling stage and maintaining low severity to stem rust in the field across a range of environments (Singh et al. 2008; Njau et al. 2009; Onguso and Njau 2015), confirming that these cultivars have race non-specific resistance to stem rust. Paka and Popo have race-specific resistance gene(s) that are effective against the prevalent stem rust races in South Africa. The presence of $\mathrm{Sr} 35$ was only confirmed in Popo using the $\operatorname{Sr} 35$ linked marker. The same results were obtained by Bajgain et al. (2016) and Prins et al. (2016). Although marker data was in agreement in these studies, the seedling phenotype of Popo did not give similar results. This could be explained by use of different source of seed as cultivar Popo in the aforementioned studies showed seedling susceptibility to races within the Ug99 lineage which is not supported by the presence of $\mathrm{Sr} 35$ (a race-specific gene effective against several Ug99 races) (Njau et al. 2009; Bajgain et al. 2016; Prins et al. 2016).

Since all eight Kenyan cultivars were confirmed to have APR resistance to stem rust in multiple environments in South Africa, North America, and Kenya (Njau et al. 2009; Bajgain et al. 2016; present study), they certainly carried multiple useful APR genes to stem rust. To date, more than five APR genes have been identified and validated by several studies (Sr2/Yr30/Lr27/Pbc1, Sr55/Lr67/Yr46/Pm46/Ltn3, Sr57/Lr34/Yr18/Pm38/ Ltn1, Sr58/Lr46/Yr29/Pm39/Ltn2 and Lr68) and confer resistance not only to stem rust but also to other diseases such as leaf rust, yellow rust and powdery mildew of wheat (William et al. 2006; Lillemo et al. 2008; Krattinger et al. 2009; Herrera-Foessel et al. 2011; Mago et al. 2011a; Herrera-Foessel et al. 2014; Kolmer et al. 2015). Of the reported genes, our results were in agreement with that of Bajgain et al. (2016) that Gem, Kudu, Paka and Romany all carry the $S r 2$ gene. In our study, four of these cultivars Gem, Fahari, Kudu and Ngiri tested positive for Sr57/Lr34 using the allele specific markers (cssfr1, cssfr 2, cssfr 3 and cssfr 4 ). The $S r 57$ results were different from those of Bajgain et al. 
(2016) as they found none of these cultivars tested positive for Sr57. Due to different levels of APR resistance present in these eight cultivars based on results from multi-environment testing trials (Njau et al. 2009; Bajgain et al. 2016; and the current study), new APR genes could be present in these cultivars in combination with race-specific resistance genes. Efforts were made to map the APR genes using these cultivars in a nested mating design with LMPG-6 as a common parent (Bajgain et al. 2016), and several QTL regions were identified as significant, some co-localizing with known location of defeated genes and some as new genes.

The five APR genes for wheat stem rust resistance have also been shown to confer resistance to leaf rust at adult plant stage. Most APR genes have susceptible reactions to leaf rust at seedling stage (Kolmer 1996; Tsilo et al. 2014). Since only Gem, Pasa, Paka and Popo showed resistance to all four predominant races of leaf rust in South Africa at seedling stage, these cultivars carry effective race-specific resistance genes to leaf rust. Using diagnostic markers, all the eight cultivars proved not to carry $\operatorname{Lr} 9$ and $\operatorname{Lr} 19$ resistance genes. Hence, it is speculated that these cultivars may have uncharacterised resistance genes to leaf rust or a combination of other characterised leaf rust resistance genes not tested in this study. For APR genes, only four cultivars Gem, Fahari, Kudu and Ngiri tested positive for Lr34/Sr57 using the allele specific markers (cssfr1, cssfr2, cssfr 3 and cssfr4) as mentioned before. It will be interesting to see if other new APR genes for stem rust are also responsible for leaf rust resistance observed in the current study. This is highly possible as most of these APR genes have pleiotropic effects, and also do not confer adequate levels of resistance when present singly (Kolmer 1996; Singh et al. 2013; Silva et al. 2015). The nested bi-parental population developed using the eight Kenyan cultivars in the backgrounds of Kariega and Morocco will therefore provide a powerful tool for identifying the 'unconfirmed or unknown' APR genes or QTLs controlling resistance to leaf rust and stem rust and possibly other economically important traits. It will be interesting to see if QTLs that will be identified using the nested bi-parental population developed in the current study will be the same QTLs detected by Bajgain et al. (2016), who used the same Kenyan cultivars in a different background of LMPG-6.

This study has shown that the tested Kenyan wheat cultivars exhibit adult plant resistance not only to stem rust but also to leaf rust. Screening with molecular markers only confirmed the presence of two APR genes, i.e. Sr2/Yr30/Lr27/Pbc1 and Sr57/Lr34/Yr18/ Pm38 in some of the cultivars, hence the consideration to deploy the varieties in constructing a nested bi-parental population that will add value in the identification and validation of a new set of APR genes that are present in these cultivars. The principal effect of APR genes in controlling slow rusting in the studied cultivars highlighted the value of having them as sources of durable resistance. The genetic resource developed in this study will be a useful tool for identifying the 'unconfirmed or unknown' APR gene(s) controlling leaf rust and stem rust diseases. 


\section{Acknowledgements}

The authors thank the technical staff of the Agricultural Research Council-Small Grain Institute in South Africa for their assistance during field trials and data collection. The Agricultural Research Council, Winter Cereal Trust and the National Research Foundation of South Africa are highly acknowledged for funding this study. The authors have no conflict of interest to declare.

\section{References}

Bajgain, P., Rouse, M.N., Tsilo, T.J., Macharia, G.K., Bhavani, S., Jin, Y., Anderson, J.A. 2016. Nested association mapping of stem rust resistance in wheat using genotyping by sequencing. PloS One 11:e0155760.

Bansal, U., Bariana, H., Wong, D., Randhawa, M., Wicker, T., Hayden, M., Keller, B. 2014. Molecular mapping of an adult plant stem rust resistance gene Sr56 in winter wheat cultivar Arina. Theor. Appl. Genet. 127:1441-1448.

Herrera-Foessel, S.A., Lagudah, E.S., Huerta-Espino, J., Hayden, M.J., Bariana, H.S., Singh, D., Singh, R.P. 2011. New slow-rusting leaf rust and stripe rust resistance genes $\operatorname{Lr} 67$ and $Y r 46$ in wheat are pleiotropic or closely linked. Theor. Appl. Genet. 122:239-249.

Herrera-Foessel, S.A., Singh, R.P., Huerta-Espino, J., Rosewarne, G.M., Periyannan, S.K., Viccars, L., CalvoSalazar, V., Lan, C., Lagudah, E.S. 2012. Lr68: a new gene conferring slow rusting resistance to leaf rust in wheat. Theor. Appl. Genet. 124:1475-1486.

Herrera-Foessel, S.A., Singh, R.P., Lillemo, M., Huerta-Espino, J., Bhavani, S., Singh, S., Lan, C., CalvoSalazar, V., Lagudah, E.S. 2014. Lr67/Yr46 confers adult plant resistance to stem rust and powdery mildew in wheat. Theor. Appl. Genet. 127:781-789.

Johnson, R. 1984. A critical analysis of durable resistance. Ann. Rev. Phytopathol. 22:309-330.

Knott, D. 1968: The inheritance of resistance to stem rust races 56 and 15B-1L (Can.) in the wheat varieties Hope and H-44. Canad. J. Genet. Cytol. 10:311-320.

Kolmer, J. 1996. Genetics of resistance to wheat leaf rust 1. Annu. Rev. Phytopathol. 34:435-455.

Kolmer, J.A. 2005. Tracking wheat rust on a continental scale. Curr. Opin. Plant Biol. 8:441-449.

Kolmer, J.A., Lagudah, E.S., Lillemo, M., Lin, M., Bai, G. 2015. The Lr46 gene conditions partial adult-plant resistance to stripe rust, stem rust, and powdery mildew in Thatcher wheat. Crop Sci. 55:2557-2565.

Kolmer, J., Acevedo, M. 2016. Genetically divergent types of the wheat leaf fungus Puccinia triticina in Ethiopia, a center of tetraploid wheat diversity. Phytopathol. 106:380-385.

Krattinger, S.G., Lagudah, E.S., Spielmeyer, W., Singh, R.P., Huerta-Espino, J., McFadden, H., Bossolini, E., Selter, L.L., Keller, B. 2009. A putative ABC transporter confers durable resistance to multiple fungal pathogens in wheat. Science 323:1360-1363.

Lagudah, E., Mcfadden, H., Singh, R., Huerta-Espino, J., Bariana, H., Spielmeyer, W. 2006. Molecular genetic characterization of the $L r 34 / Y r 18$ slow rusting resistance gene region in wheat. Theor. Appl. Genet. 114: 21-30.

Lillemo, M., Asalf, B., Singh, R., Huerta-Espino, J., Chen, X., He Z., Bjørnstad, Å. 2008. The adult plant rust resistance loci $\mathrm{Lr34} / \mathrm{Yr} 18$ and $\mathrm{Lr} 46 / \mathrm{Yr} 29$ are important determinants of partial resistance to powdery mildew in bread wheat line Saar. Theor. Appl. Genet. 116:1155-1166.

Long, D., Kolmer, J. 1989. A North American system of nomenclature for Puccinia recondita f. sp. tritici. Phytopathol. 79:525-529.

Mago, R., Tabe, L., McIntosh, R.A., Pretorius, Z., Kota, R., Paux, E., Wicker, T., Breen, J., Lagudah, E.S., Ellis, J.G., Spielmeyer, W. 2011a. A multiple resistance locus on chromosome arm 3BS in wheat confers resistance to stem rust $(S r 2)$, leaf rust ( $L r 27)$ and powdery mildew. Theor. Appl. Genet. 123:615-623.

Mago, R., Brown-Guedira, G., Dreisigacker, S., Breen, J., Jin, Y., Singh, R., Appels, R., Lagudah, E.S., Ellis, J., Spielmeyer, W. 2011b. An accurate DNA marker assay for stem rust resistance gene $\mathrm{Sr} 2$ in wheat. Theor. Appl. Genet. 122:735-744. 
McCallum, B.D., Hiebert, C.W., Cloutier, S., Bakkeren, G., Rosa, S.B., Humphreys, D.G., Marias, G.F., McCartney, C.A., Panwar, V., Rampitsch, C., Saville, B.J., Wang, X. 2016. A review of wheat leaf rust research and the development of resistant cultivars in Canada. Can. J. Plant Pathol. 38:118.

McIntosh, R.A., Wellings, C.R., Park, R.F. 1995. Wheat rusts: an atlas of resistance genes. CSIRO Publishing. East Melbourne, Victoria 3002, Australia.

Njau, P., Wanyera, R., Macharia, G., Singh, J.M.R., Keller, B. 2009. Resistance in Kenyan bread wheat to recent eastern African isolate of stem rust, Puccinia graminis f. sp. tritici, Ug99. J. Plant Breed. Crop Sci. 1:022-027.

Njau, P.N., Jin, Y., Huerta-Espino, J., Keller, B., Singh, R.P. 2010. Identification and evaluation of resistance to stem rust race Ug99 in wheat. Plant Dis. 94:413-419.

Onguso, J., Njau, P. 2015. Screening of Kenyan bread wheat varieties for resistance to the emerging strains of stem rust fungi (Puccinia graminis f. sp. tritici) race Ug99. World J. Agri. Res. 3:5-10.

Parlevliet, J.E., van Ommeren, A. 1975. Parital resistance of barley to leaf rust, Puccinia hordei. II. Relationship between field trials, micro plot tests and latent period. Euphytica 24:293-303.

Peterson, R.F., Campbell, A., Hannah, A. 1948. A diagrammatic scale for estimating rust intensity on leaves and stems of cereals. Canad. J. Res. 26:496-500.

Porebski, S., Bailey, L.G., Baum, B.R. 1997. Modification of a CTAB DNA extraction protocol for plants containing high polysaccharide and polyphenol components. Plant Mol. Bio. Rep. 15:8-15.

Pretorius, Z., Pakendorf, K., Marais, G., Prins, R., Komen, J. 2007. Challenges for sustainable cereal rust control in South Africa. Crop Past. Sci. 58:593-601.

Pretorius, Z., Singh, R., Wagoire, W., Payne, T. 2000. Detection of virulence to wheat stem rust resistance gene Sr31 in Puccinia graminis. f. sp. tritici in Uganda. Plant Dis. 84:203.

Pretorius, Z., Visser, B., Terefe, T., Herselman, L., Prins, R., Soko, T., Siwale, J., Mutari, B., Selinga, T.I., Hodson, D.P. 2015. Races of Puccinia triticina detected on wheat in Zimbabwe, Zambia and Malawi and regional germplasm responses. Australas. Plant Path. 44:217-224.

Prins, R., Dreisigacker, S., Pretorius, Z., van Schalkwyk, H., Wessels, E., Smit, C., Bender, C., Singh, D., Boyd, L.A. 2016. Stem rust resistance in a geographically diverse collection of spring wheat lines collected from across Africa. Front. Plant Sci. 7:973.

Silva, P., Calvo-Salazar, V., Condón, F., Quincke, M., Pritsch, C., Gutiérrez, L., Castro, A., Herrera-Foessel, S., von Zitzewitz, J., Germán, S. 2015. Effects and interactions of genes Lr34, Lr68 and Sr2 on wheat leaf rust adult plant resistance in Uruguay. Euphytica 204:599-608.

Singh, A., Pandey, M., Singh, A., Knox, R., Ammar, K., Clarke, J., Clarke, F., Singh, R.P., Pozniak, C.J., DePauw, R.M., McCallum, B.D., Cuthbert, R.D., Randhawa, H.S., Fetch Jr, T.G. 2013. Identification and mapping of leaf, stem and stripe rust resistance quantitative trait loci and their interactions in durum wheat. Mol. Breed. 31:405-418.

Singh, R., Huerta-Espino, J., Rajaram, S., Barna, B., Kiraly, Z. 2000. Achieving near-immunity to leaf and stripe rusts in wheat by combining slow rusting resistance genes. Acta Phytopathol. Entomol. Hung. 35:133-139.

Singh, R.P. 1992. Association between gene Lr34 for leaf rust resistance and leaf tip necrosis in wheat. Crop Sci. 32:874-878.

Singh, R.P., Huerta-Espino, J., William, H.M. 2005. Genetics and breeding for durable resistance to leaf and stripe rusts in wheat. Turk. J. Agric. For 29:121-127.

Singh, R.P., Hodson, D.P., Huerta-Espino, J., Jin, Y., Njau, P., Wanyera, R., Herrera-Foessel, S.A., Ward, R.W. 2008. Will stem rust destroy the world's wheat crop? Adv. Agron. 98:271-309.

Stakman, E.C., Stewart, D.M., Loegering, W.Q. 1962. Identification of physiologic races of Puccinia graminis var. tritici. U.S, Agric. Res. Serv. ARS E617:1-53.

Terefe, T., Visser, B., Herselman, L., Selinga, T., Pretorius, Z. 2014. First report of Puccinia triticina (leaf rust) race FBPT on wheat in South Africa. Australas. Plant Path. 44:217.

Tsilo, T.J., Kolmer, J.A., Anderson, J.A. 2014. Molecular mapping and improvement of leaf rust resistance in wheat breeding lines. Phytopathol. 104:865-870.

William, H.M., Singh, R.P., Huerta-Espino, J., Palacios, G., Suenaga, K. 2006. Characterization of genetic loci conferring adult plant resistance to leaf rust and stripe rust in spring wheat. Genome 49:977-990. 